\title{
THE SALA DE INVESTIGACIONES- FONDO RESERVADO OF THE UNIVERSITY OF SAN MARCOS CENTRAL LIBRARY, LIMA, PERU
}

The Universidad Nacional Mayor de San Marcos (UNMSM) was founded in 1551 in Lima, Peru, and for centuries has remained the major university in the country. But during the past several decades, a number of other universities, both public and private, have been created in Lima, and San Marcos now shares with them a space that, until the mid-twentieth century, was almost exclusively its own. Today, the rare book and manuscript collections within the library system are among the most important in the country. A recent development has been the creation of the Sala de Investigaciones Bibliográficas-Fondo Reservado, ${ }^{1}$ which contains the rare books, manuscripts, and older materials of the UNMSM library system. This collection reflects historical developments in both the university and the country as a whole.

The first section of this paper presents a brief history of the San Marcos University and its library; the second part describes the collections that make up the Fondo Reservado. The third and final section provides an account of the Fondo Reservado's current activities and its future plans, focusing primarily on collection management and issues pertaining to accessibility, visibility, and conservation.

\section{San Marcos and Its Libraries}

Myth and reality frequently become one when Peruvians talk about their homeland, an Andean country located in an area that has been populated for millennia. It is not uncommon when describing the University of San Marcos, locally known as the Dean of the American Uni-

1. The Sala de Investigaciones Bibliográficas was opened in 1994 , when the central library still occupied an off-campus building in downtown Lima.Also in that year, an ad hoc team selected the Fondo's holdings. In 1999, the library left its old facilities and moved into a new library building located on the UNMSM campus. 
versities, for people to speak as if the library's history goes back as far as that of the university. ${ }^{2}$ If that were the case, how wonderful it would be, for then the library's collection (and, ideally, preservation) efforts would have begun in the mid-sixteenth century. But, unfortunately, the history of the library's beginnings differs significantly from that of the university as a whole. In fact, the current library is a relatively recent addition to the university.

The University of San Marcos, founded in 1551 and officially recognized by a royal decree of Charles I of Spain in the same year, is the oldest university in the Americas. That very year, a few months later, the Crown authorized the foundation of the Royal and Pontifical University of Mexico, and there has been a long-standing dispute as to which university is older. ${ }^{3}$ The Crown's decision to create a university in Lima, the capital of the Viceroyalty of Peru, was in keeping with the city's importance to Spanish colonial rule in South America. Until the end of that rule in 1821, Lima, the most important Spanish-American port on the South American Pacific coast, was Spain's main administrative center for the whole region.

The earliest account referring to a library at the university indicates that in 1768 the university petitioned the viceroy of Peru, Don Manuel Amat, to turn over all the books the government had confiscated from the library of the Peruvian Jesuit Order following their banishment from Peru in 1767 . In its petition to the viceroy, the university described the Jesuit Library as "complete in scriptural, theological, moralist and historical authors; poets; ecumenical councils and Fathers of the Church as well as canonists. It is weak in authors of Civil and Practical Law."4 Although the books were eventually installed in the San Marcos library, it is not known exactly when this occurred.

2. According to Koestler's definition, myths are "beliefs which are not only incompatible with observable facts, but with facts actually observed by us."Arthur Koestler, "Anatomy of a Myth," in The Yogi and the Commissar (New York: Collier Books, 1945), 111.

3. For a discussion on the topic of precedence in time, see UNMSM, "¿Es la Universidad de Lima la más antigua de América?," Boletín Bibliográfico. Publicado por la Universidad Nacional Mayor de San Marcos de Lima 8, no. 2 (July 1938): 141-43; also Miguel Maticorena, San Marcos de Lima universidad decana de América: una argumentación bistórico-jurídica (Lima: Fondo Editorial UNMSM, 2000).

4. Carlos A. Romero, "La Biblioteca de la Universidad Nacional Mayor de San Marcos y el Bibliotecario fray Diego Cisneros," Boletín Bibliográfico UNMSM 3, no. 1 (June 1927): 36. See also Federico Schwab, "Libros en latín de la Antigua biblioteca de la Universidad Mayor de San Marcos," Boletín Bibliográfico 26, no. 1-4 (Dec. 1956): 3-42. 
The Jesuits' books remained in the UNMSM library only until 1822, one year following Peru's independence from Spain. In September of that year, in compliance with a governmental decree, the university's collections were turned over to the Biblioteca de Lima (today's Peruvian National Library), which had been created the previous year. In another decree issued in 1822, it was dictated that some of the university's properties would be taken over by the Congress of the Republic of Peru to be used by the congress "while a new House is being built to this purpose." Thus, the University of San Marcos entered Republican times dispossessed of its library as well as having lost many of its original buildings. But as painful as these events were, especially to the university officials forced to live under such conditions for the next several decades, they must be viewed in their historical context. The commanders of the Liberating Army were not native Peruvians and thus lacked a respect for many of Peru's cultural and historic institutions, recognizing only that the nascent republic needed new institutions. Also, the old university, which was closely identified with the colonial establishment, had fallen into a period of intellectual stagnation that contrasted greatly with the vitality of the newer Colegio de San Carlos (1771) and Colegio de San Fernando (1811). In fact, the local independentist elite had received their education from these two newer colleges rather than from San Marcos. In 1879, when referring to this period, the dean of the San Marcos Faculty of Law dramatically stated that: "The old University of San Marcos was the perfect expression of the colonial system ... The university collapsed together with the viceroyalty ... The old university fell, but a new one did not rise."6

During the next forty years, the University of San Marcos managed to coexist with the colegios, institutions that offered both basic and higher learning to their students, by administering sufficiency exams and providing some of the colegios' graduates with university degrees. ${ }^{7}$ But the political environment in Peru was, in fact, not much better than it had been prior to the country's gaining its independence. For almost the following three decades, Peru lived through a period of continuous civil war and political instability. Not until the mid-nineteenth century

5. Both decrees are reproduced in "La casa de la Universidad es tomada para las sesiones del Congreso," Anales Universitarios 1 (1862): 83-84.

6. J.A. Barrenechea, "Memoria leída por el Decano de la Facultad de Jurisprudencia de la Universidad de San Marcos el 27 de Diciembre de 1874," Anales Universitarios 8 (1876): 39.

7. See Section B (Tesis, exámenes, disertaciones, 1821-1850) in "Contribución para una bibliografía de la historia de la Universidad Nacional Mayor de San Marcos." Boletín Bibliográfico UNMSM 21, no. 1-4 (Dec. 1951): 101-4. 
did the political turmoil start to recede and a new period of stability and relative prosperity commence as a result of a rapidly growing export trade in guano (bird droppings used as fertilizer). ${ }^{8}$

Beginning in 1855, and continuing over the course of the next two decades, Peruvian politicians and educators addressed the necessity of reforming the country's educational system. The initiative came in the form of an 1855 law that stated: "A university is the reunion of the following five faculties: Theology, Law, Medicine, Philosophy and Letters, and Natural Science." But although the "Reformed University" did not become official until 1861, the university had already been changing, acquiring a basic institutional structure that would continue until the third decade of the twentieth century. In 1856, the Colegio de San Fernando was incorporated into the University of San Marcos as its Faculty of Medicine. In 1866, the prosperous Colegio de San Carlos was divided into three faculties-Law, Science, and Letters-and also was assimilated by the university. Colegio de Santo Toribio temporarily became the university's Faculty of Theology but later reverted back to the jurisdiction of the Catholic Church. In 1875, the university opened the Faculty of Political and Administrative Science to train public officials. This merging with the colegios played a significant role in increasing the university's revenues and property. ${ }^{10}$

Although the university's 1861 statute referred to the creation of a library, it was not until 1871, partly due to the aforementioned developments, that concrete action aimed at establishing a library actually began to take place. In June 1871, responding to a request from Dr. Juan Antonio Ribeyro, rector of San Marcos between 1868 and 1886, the government designated Mariano Torres as San Marcos's librarian-archivist. ${ }^{11}$ By the following year, Torres had put in order the university's old documents, including the intricate colonial legal papers dealing with its property and revenues. In the same period, he created a catalog arranged in alphabetical order by author for the library: "I have not confined my-

8. The Peruvian historian Jorge Basadre has called it a "fallacious prosperity"; see his Historia de la República del Perú (Lima: Cultura Antártica, 1946), v. 1, 183, 225-46.

9. Reforma Universitaria. Reglamento de 7 de Abril de 1855 sobre Instrucción Pública," Anales Universitarios 1 (1862): 119.

10. See "Instalación de la Universidad Reformada," Anales Universitarios 1 (1862): 233-40. The governmental decrees regarding the colegios are reproduced in "Decretos y nota dictatoriales sobre reformas universitarias en 1866," Anales Universitarios 3 (1869): 79-86.

11. The official document appointing him is reproduced in "Nota de la Dirección de Instrucción comunicando el nombramiento de archivero bibliotecario en favor de D. Mariano Torres," Anales Universitarios 6 (1871): 65. 
self to classifying the books according to only the [initial] letter [of the author's surname], but also within each letter I have followed a strict alphabetic order," he wrote in a report to the rector on July 19, 1872. ${ }^{12}$ Such an observation is indicative of the nature of the changes that were taking place in people's minds, for up until that time, "alphabetical order" had frequently meant considering only the first letter of the name when grouping together first names, without regard to second or subsequent letters (i.e., an "alphabetized" list of first names could appear as Miguel, Martin, Manuel). In the following years, Torres also compiled the university's historical and academic archive.

Dr. Juan Antonio Ribeyro's administration stands out not only because he was responsible for instituting the university library, but also because he conceived of the library as an integral part of academic life. Legislators, deans, and rectors of that period frequently spoke of university reforms that were being implemented in the United States and Europe, yet few of those officials emphasized the importance of the academic role of libraries as did Ribeyro. Indeed, in reading from his annual report of December 1872 , he devoted a long section to the work of the library and the important role it plays in learning. It is telling that the section pertaining to the library followed immediately after his report on the faculties, but before a description of the university's publications, external affairs, etc. Some descriptions of the library's holdings at the time are still in print: the publication of the university library's catalog, the publication of old manuscripts dealing with the founding of the colegios San Carlos and San Fernando, the inventory of the documents relevant to the Colegio de San Carlos' revenues (391 documents), and the university's signing of the declaration of independence. ${ }^{13}$ In Ribeyro's eyes, although university reform began late, it was the ultimate manifestation of modernity in higher education: "year after year passed and the old viceroyalty's practices remained alive in a whole segment of the public administration. Only very recently those practices have started to disappear, and we do not expect them to return ... What was this institution in 1860 ?14 [author's emphasis] Ribeyro's rhetorical question posed in 1871 highlights the dramatic nature of those changes and how relatively quickly they took

12. Copiador de las comunicaciones oficiales é informes de la Biblioteca y archivo de la Universidad.Abierto en 19 de Julio de 1871.19/VII/1872: 7-8. Documentos Históricos. Fondo Reservado UNMSM.

13. The catalog was published in Anales Universitarios 6 (1871): xciii-clii, the inventory in lix - xcii, and the other documents in Anales Universitarios 8 (1876): 183-209.

14. "Discurso pronunciado por el Rector de la Ilustre Universidad Mayor de San Marcos, al abrirse el año escolar de 1871." Anales Universitarios 6 (1871): 27. 
place. However, the War of the Pacific (1879-1883), which was waged as Chile sought to gain lands belonging to Bolivia and Peru, brought this promising period for the university and its library to an abrupt end. In January 1881, Chilean troops entered the defeated city of Lima. The years of occupation that followed constituted a national catastrophe that had devastating effects. Occupation troops looted both the National Library and the San Marcos library. When the occupying armies finally left Peru in 1883, less than five hundred mutilated books and a few documents remained in the university library. One of these documents was a manuscript register titled Copiador de las comunicaciones oficiales é informes de la Biblioteca y archivo de la Universidad. Abierto en 19 de Julio de 1871 (Register of the official communications and reports from the university's library and archive. Opened in July 19, 1871), which included a handwritten account of the library's activities. An average of fifteen entries per year of varied nature and length (ranging from three lines to three pages) was recorded between 1871 and 1878. All these serve as evidence of the optimism and commitment of the university's rector and librarian when they established the library. For the following year, 1879, there are only three entries. Nothing further is indicated until 1887, when finally eight brief transactions for borrowed materials appear. There is a sharp contrast between the paucity of the library's register between 1879 and 1887 and the quantity of correspondence kept by the rector during 1882 and $1886 .^{15}$

The library, which had been such a promising university initiative when it began in 1871, was reduced to practically nothing and closed its doors for almost twenty years. It did not reopen until 1904. Fueled in part by British and American investments, the library's reopening coincided with the beginning of a period of modernization that generated new social movements in Peru. Although these developments were more or less common to all the Latin American countries, in Peru they had their own characteristics. When Chile, a country with fairly cohesive societal and institutional structures defeated Peru, the sociological complexities of Peru's various indigenous populations were brought to light. In 1888, this situation was described in a speech written by the Peruvian writer, Manuel González Prada, and read by a schoolchild before an audience assembled for a patriotic demonstration in Lima: "The clusters of criollos

15. "During the thirty-four months of the assault ... innumerable witnesses declared that the soldiers would sell at barrio stores-by weight—not only books, but also bundles of documents from the [university] archive." From "Saqueo de la Universidad," Anales Universitarios 13 (1887): 275. Handwritten copies of the official communications from the rectorial office are bound in an untitled volume in the Fondo Reservado.This book and the Copiador de las comunicaciones oficiales belong to the Fondo Reservado's collection of historical documents. 
and foreigners who live in the strip of land between the Pacific and the Andes do not constitute the true Peru; the nation is made up by the crowds of Indians situated over the Eastern slopes of the sierras." ${ }^{16}$ In this speech, Prada, a veteran of the war whose family was of the white coastal elite centered in Lima, helped to signal a turning point in how Peruvians viewed themselves and their country. During this period, intellectuals in Peru were gaining a richer view of their homeland, delving deeper into their historical roots and broadening their perspectives, and becoming more critical of the past. But for some years into the twentieth century, the university establishment, under the tight control of Lima's more elite population, ignored its changing surroundings. Finally, in 1919, a student movement arose that included middle-class students of provincial origin. They called for a more outward-looking university and faculty renewal. They became known as the Generation of the Centennial (of Peru's independence, 1921), and were led by a singularly talented group of young leaders who in the next years would collaborate with the university library as it went through a period of radical changes.

Two years after the library reopened in 1904, it published the Catálogo de la Biblioteca de la Universidad Mayor de San Marcos (Lima: Sanmartí, 1906), which was followed by three supplements in 1908, 1909, and 1911. These publications portray the state of the collections at San Marcos, which at the time included more than 6,400 titles. The second supplement is particularly important because it describes 1,724 volumes that were donated to the library following the death of Pedro Carlos Olaechea (1865-1907), a jurist and former professor at UNMSM. The Olaechea donation, which was composed of many European and Latin American law books, helped to compensate for an imbalance in the collection that had previously been noted by a young Peruvian intellectual, Francisco García Calderón. In describing the library's collection prior to the Olaechea donation, he had stated: "The library is very rich in the section of letters, in books on philosophy, esthetics, sociology and history; it is not as rich in works on law and economics." ${ }^{17}$ Dr. Pedro Carlos Olaechea is remembered as the library's "first benefactor." 18

16. Manuel González Prada, "Discurso en el Politeama," Pájinas Libres (Lima: PTCM, 1946), 67.

17. Francisco García Calderón, "La apertura de nuestra biblioteca en 1904," Boletín Bibliográfico UNMSM 1, no. 6 (Dec. 1923): 81.

18. See Francisco Siverio, "Los benefactores de la Biblioteca de la Universidad Mayor de San Marcos," Boletín Bibliográfico UNMSM 10, no. 1-2 (June 1940):363-283. Olaechea's title as "first benefactor" appears as a caption to his portrait on a plate between pages 360 and 361 . 
Between 1923 and 1924, the library introduced important innovations: new cataloging methods and modern library cards were used (the library ordered its materials from the Library Bureau, the American library supply company founded by Melvil Dewey in 1876); collections were updated to include the most recent books; connections were established with other libraries; services were expanded specifically targeting the city's new working class; and the library initiated publication of its Boletín Bibliográfico. These changes were introduced by Pedro Zulen (1889-1925), a Chinese-Peruvian philosopher and social activist who was appointed university librarian in 1923 by Rector Manuel Vicente Villarán (1873-1958), a well-known critic of the traditional Peruvian educational system. Villarán and Zulen had previously met when Zulen was a student worker at the university's library between 1912 and 1913. In 1920, Zulen was admitted to Harvard University, where he took graduate classes in philosophy and psychology as well as what would later be called "library science." It was at Harvard that Zulen began to formulate his plans for the modernization of the library at the University of San Marcos. In 1922, Villarán invited Zulen to return to Peru to catalog the holdings of the University of San Marco's library, where he was assisted by a group of students that included some of the leaders of the 1919 movement. Together, they began publishing the Boletín Bibliográfico, collaborating on its editing and distribution. One of the students who worked at the library, Jorge Basadre (1903-1980), said of Zulen's work: "He brought to the library, in a way that was almost unnoticed, the fast pace of the most privileged cultural centers, and made of it not a bureaucratic center but a dynamic tool." 19

Although of seminal importance, Zulen's time at San Marcos was cut short by his unfortunate death in January 1925. By then, the library had cataloged 16,000 of its 31,200 books (a significant increase from the 20,000 it had in 1919). The catalog was completed between 1936 and 1941 when Jorge Basadre, by then an accomplished historian, became the university librarian. The Boletín Bibliográfico continued to be published through issue number 78 in 1966, when it appeared for the last time.

As the reputation of the library grew, important donations continued to be made to its Peruvianist collections. In 1947, when the UNMSM's libraries had approximately 110,000 books, the library was reorganized 
under the supervision of American librarian Arthur M. McAnally (who was director of the library at the University of New Mexico at the time), and it adopted the U.S. Library of Congress cataloging rules. The students who had worked at the library with Pedro Zulen came to occupy leading positions in the country. In general, the Generation of the Centennial was a major influence in Peru, and for most of the twentieth century its actions and ideas shaped the country. In 1974, a Peruvian historian said of them: "Many of their ideas have not been surpassed yet ... All that intellectual mass has lasted fifty years; this is an exceptional phenomenon in Peru. In all our history, since the sixteenth century no group has exerted a bigger influence nor has it lasted for so long." ${ }^{20}$ In 1994, a final selection of materials for placement in the Fondo Reservado was made by professors who were disciples of some of the students who collaborated with Pedro Zulen at the university library. ${ }^{21}$ In 2002, the central library was named after him.

\section{The Collections of the Fondo Reservado}

The Fondo Reservado and its Sala de Investigaciones Bibliográficas are located on the lower level of the Pedro Zulen Central Library (Plaza de los Molles, Ciudad Universitaria UNMSM, Lima). It has 1,350 feet of bookshelves, 630 of which contain collections of rare books that date from the sixteenth through the eighteenth centuries. The remaining shelves are filled with the other collections of the Fondo Reservado, including rare pamphlets, periodicals, the library's historical documents, 30 Years of Peruvian Poetry, 1971-2000, and the José Carlos Mariátegui's Library (an historical reconstruction).

\section{Rare Books}

This collection contains 9,200 volumes, most of which date from the nineteenth and twentieth centuries. It is particularly strong in the history of both Lima and Peru during the national period. Research material also is available on the history of Peru's borders from the time of its independence, when it began sharing borders with the nascent South American countries of Colombia, Ecuador, Brazil, and Bolivia. Documents recording the period following the War of the Pacific, when Peru found itself sharing borders with Chile and was forced to enter into long negotiations with that country in order to establish definitive boundaries also are included

20. Pablo Macera, Conversaciones con Basadre (Lima: Mosca Azul, 1979), 11-12.

21. Dr. Raúl Rivera (history), Prof. Miguel Maticorena (history), Dra. Esther Castañeda (literature), and Lic.Tabita Fernández (Central Library). 
in the collection. Many of these books (e.g., treatises on international law or compilations of diplomatic documents) have either come to the library as donations or were presented as gifts directly by their authors.

The Rare Book Collection includes 43 books from the sixteenth century, 167 from the seventeenth century, and 200 books from the eighteenth century. Most of these books are devoted to philosophy, religion, and the vast body of Spanish and colonial Spanish American legislation. More than forty of these books were printed in Lima. A significant title in this collection is the Chronica moralizada del orden de S. Avgustin en el Perú (Barcelona: Pedro Lacavallería, 1639-1653) by Antonio de la Calancha, an Augustinian priest who wrote a baroque narrative about the history of his order in Peru. His account is interspersed with moralistic and instructive observations drawn from the scriptures as well as the writings of the Fathers of the Church. An outstanding example of a book from the sixteenth century is Jesuit Joseph de Acosta's Historia Natural y Moral de las Indias (Barcelona: Iayme Cendrat, 1591), a strikingly "modern" comparative study of the peoples and cultures of Peru, Mexico, and several Asian civilizations. In this collection also are some Peruvian "classics," including books by Inca Garcilaso de la Vega (1539-1616), a chronicler and historian, the son of a Spanish nobleman soldier and also the grandnephew of the last great emperor of the Incas, Huayna Capac. The books include Historia General del Perú (Córdova: Viuda de Andrés Barrera, 1617; Madrid Oficina Real, y a costa de Nicolas Rodríguez Franco, 1722); La Florida del Inca (Madrid: Nicolás Rodríguez Franco, 1723); and his famous Comentarios Reales de los Incas (Lisbona: Casa de Pedro Crasbeek, 1608). The most important manuscript in this collection is a copy of the Libro 10. del Nuevo Código de Leyes de Indias (1st. Book of the New Law Code for the Indies), one of three known copies composed by a committee charged in 1776 by King Charles III with the task of arranging a new codification of the 1680 Compilation of the Laws for the Indies. The project was never completed. ${ }^{22}$

The oldest book in this collection is Vincenzo Carocci's, Tractaus de remediis contra praeivdiciales sententias, vel damnosos executiones (Treaty of remedies against detrimental sentences or harmful executions) printed in Geneva (Coloniae Allobrogvm: Philippvm Albert, 1521). This book was originally part of the Jesuit library obtained by the San Marcos 
library following the expulsion of the Jesuits from the country at the end of the eighteenth century. In 1822, it was brought to the Biblioteca de Lima, where it survived the looting that took place during the War of the Pacific and a devastating fire that destroyed the Peruvian National Library in 1943. Later, Jorge Basadre, who was commissioned with the task of reconstructing the National Library, decided that this book and others of similar origin should be returned to the university library.

The books and pamphlets collected by the Peruvian archaeologist Julio C. Tello (1880-1947) also are part of this collection. Tello, the founder of scientific archaeology in Peru, graduated from the San Marcos Medical School in 1909. His thesis was entitled Antigüedad de la Sifilis en el Peru (Antiquity of Syphilis in Peru). He followed with graduate studies at Harvard and in New York, where he studied physical anthropology with Ales Hrdlicka, Franz Boas, and Frederick Putman. Throughout his career he collected an impressive personal library as well as pre-Columbian artifacts that he bequeathed to the University of San Marcos. His collection of pamphlets was bound by UNMSM in 184 volumes containing 2,075 pamphlets, booklets, and journal issues on anthropology, archaeology, natural sciences, and historical subjects.

The library's collection of rare books has been cataloged using Library of Congress cataloging rules adapted by UNMSM. All these books are accessible through the UNMSM OPAC at http://catalogo-01.unmsm.edu. pe/frame.htm.

\section{Rare Pamphlets}

This collection consists of 330 bound volumes containing a total of 3,560 pamphlets and booklets and approximately 700 single pamphlets from 1821 to 1950 . Most of these volumes were bound by the library in the 1950s, although some of those that were donated had already been bound. Almost half the pamphlets deal with history subjects. The value of this collection is its wide and varied thematic scope. Some of the booklets were written as studies of history, law, or medicine; others were legal claims, demands, or accusations. There also are official reports from private and public institutions.

The collection contains many UNMSM theses written during the second half of the nineteenth century and a number of booklets from the turn of the century devoted to new professional areas, such as engineering and education. Although the collection has not as yet been cata- 
loged, efforts in past months have been focused on creating a database accessible through the library Web site.

\section{Periodicals}

The Fondo Reservado has a collection of 230 academic journals and magazines and 90 Peruvian newspapers. Among the academic journals are the complete collections of those periodicals published by the University since 1862, including the Anales Universitarios (1862-1904), Revista Universitaria (1906-1930), Boletín Bibliográfico de la Biblioteca de San Marcos (1923-1966), Boletín Universitario (1930-1931), Revista Universitaria (Second Phase, 1935-1939), and Revista de Ciencias (1898-1964). Revista de Ciencias was a journal published by professors from the UNMSM Faculty of Sciences and is historically associated with the Peruvian mathematician Federico Villarreal (1850-1823), its founder and first editor. In 1910, Villarreal published for the first time in Peru an article on Melvil Dewey's decimal system of classification and used as an epigraph the classification of his own article: [0254 (045) (8511) "1910. 06. 05" = 6 (F. V.)]. ${ }^{23}$

\section{Library Historical Documents, 1871-1930}

The Fondo Reservado is currently in the process of collecting and arranging the library's historical documents dating from 1871 to 1930. The oldest is the above-referenced Copiador de las comunicaciones oficiales é informes de la Biblioteca y archivo de la Universidad. Abierto en 19 de Julio de 1871. It contains a register of handwritten copies of letters and reports regarding the organization and functioning of the library in the period immediately before the War of the Pacific. There also are volumes of bound typed copies of official communications from the library during the periods 19061915, 1921-1922, and 1929-1930, as well as acquisition records covering the period prior to the publication of the Boletín Bibliográfico.

\section{Years of Peruvian Poetry, 1971-2000}

The collection of recent Peruvian poetry is the result of an initiative by a number of poets (professors and students) from San Marcos. In June 2002 , the poets and the central library agreed to organize an exhibition on poetry magazines (1971-2000) to be complemented by debate sessions and poetry readings. The materials on exhibition were to be loaned to the library by their owners. During the sessions the organiz- 
ers made a call for donations, and the audience responded generously. In the next months the library received not only magazines, but also pamphlets, fanzines, leaflets, and so on from private donors as well as from publishers. The collection consists of 722 volumes of magazines (236 titles) and 195 pamphlets. Additionally, the library has digitized the 328 volumes (141 titles) of magazines that were loaned for the exhibition. This was the first time a collection had been added to the Fondo Reservado since 1994. It is particularly significant because it marks a turning point for the Fondo Reservado, which, up until this time, had functioned solely as a repository of rare and historical materials and not as a special collections library.

\section{José Carlos Mariátegui's Library}

José Carlos Mariátegui (1894-1930) was an autodidact (illness and poverty prevented him from completing his primary education) and the leading intellectual figure of the Generation of the Centennial. He was a journalist, publisher, polemicist, and political organizer. His Marxian ideas influenced much of the political and sociological debate in twentieth-century Peru.

This collection consists of 211 volumes, a number of which have Mariátegui's signature on the title page. His personal library was acquired by San Marcos in the 1930s, but by the 1970s, many of the original books were missing. The library's current goal is to assemble a collection as complete as possible based on a list of approximately 300 books that Dr. Harry Vanden, a Latin Americanist specialized in Marxist thought, has identified by using the original UNMSM acquisition records (Mariátegui: Influencias en su formación. Lima: Amauta, 1975).

\section{The Sala de Investigaciones-Fondo Reservado's Activities and Plans}

Before going into detail about the activities of the Fondo Reservado, it may be useful to put things in perspective by considering some general information. Currently, UNMSM has an enrollment of more than 29,500 undergraduates and 3,500 graduate students, as well as 3,200 professors teaching in twenty different faculties. Each faculty has its own library. The central library has a staff of 278 people, of which only 20 are professional librarians and 196 are student assistants. The central library database contains 170,000 bibliographical records; 37,600 books have yet to be cataloged. 
The Sala de Investigaciones-Fondo Reservado, a department of the UNMSM central library, is not independently managed; it does not have its own budget and depends on the technical services department of the main library for tasks such as cataloging, subject analysis and classification, and conservation binding. Bibliographical descriptions are done at the Fondo. The permanent staff of the Fondo Reservado department is made up of three people: the author of this article, who heads the department and is a historian by training; a fifth-year library science student; and an employee who is in charge of administrative matters. Eleven student assistants come to the library three times a week for six-hour shifts.

The Fondo Reservado department has existed since 1994, when its materials were selected from the library's collections and a reading room was assigned to accommodate its patrons. Visitors would consult a card catalog that contained only the collection of rare books; newspapers, periodicals, and pamphlets were not included. In 1997, the library replaced its manual card catalog with a Microisis database. Although this meant improved access of the Fondo's rare books, its other materials remained "hidden" from the public.

In 1999, two major changes occurred. First, the library moved from its old facilities in downtown Lima to a building especially built on the UNMSM main campus. Second, the library acquired its integrated library system (Sabini Systems, Spain) and migrated its existing bibliographical records, including those of the Fondo Reservado. Since then, under severe budgetary constraints, the library has been attempting to build a university union catalog by means of expanding its software to the twenty faculty libraries and three institutions affiliated with the university. Within

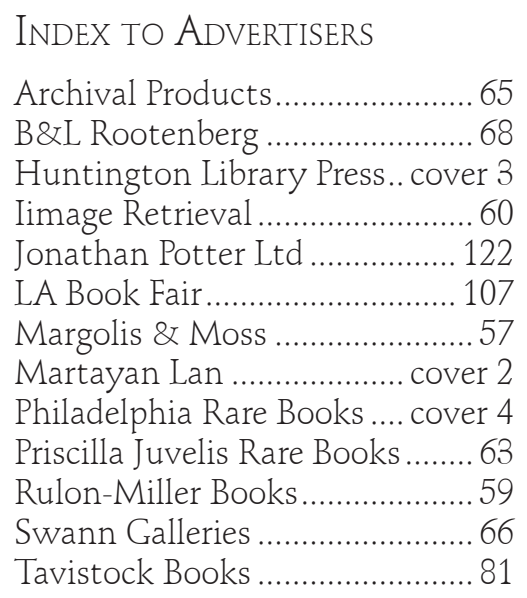
that context, the Fondo faces the challenge of making its collections accessible and publicizing its services and activities. Given the fact that almost half its materials remain uncataloged, it would not be an exaggeration to say that in many ways the Fondo is trying to overcome its invisibility.

Indeed, some of the collections in the Fondo Reservado are either insufficiently described or not 
described at all. For example, within the collection of rare books there are 2,075 pamphlets bound in 184 volumes. This collection belonged to Julio C. Tello, the renowned Peruvian archaeologist. Although most of these items are accessible thorough the library OPAC, not all the information regarding the collection has been completed or posted on the department Web site, which would enable people to browse through it. Fortunately, as a result of a recent initiative, an automation department has been created (January 2005) with the aim of supporting the library integration plans and developing the UNMSM library system Web site.

On the other hand, the Fondo faces the challenge of making visible those collections that have not yet been cataloged, including periodicals, pamphlets, and newspapers, but especially the university's historical journals. The bibliographical description of the collection of rare pamphlets is almost completed and soon will be posted on the Web. With respect to the older periodicals, the immediate goal is to post alphabetic lists that allow patrons to browse through titles. Each title will link to a page that shows all the issues published, with links to files that contain the tables of content. That is the interim goal. A decision has been made to give priority to the university's oldest journals.

Invisibility is reflected in attendance figures. The Fondo has a relatively low number of visitors and is only infrequently called upon to lend materials to other libraries. In 2004, there were five hundred visits and fewer than a thousand loans registered. Most borrowed items were nineteenth-century Peruvian newspapers (45\%) and books on Peruvian history (25\%). Unfortunately, the collection of rare pamphlets, rich in historical matters, has not been adequately publicized; only visitors who come into the library know of it. The Fondo Reservado's patrons predominantly are fourth- and fifth-year undergraduate students (70\%)

\section{Jonathan Potter Limited-}

We Buy and Sell Maps, Plans, of most periods. advice, stock lists please also send us

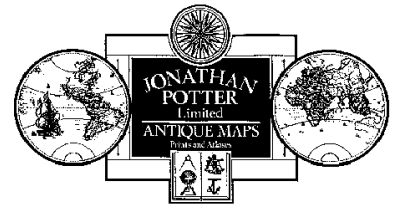

Interesting \& Rare Charts and Atlases Contact us for and catalogues, your offers.

$125 \mathcal{N}$ ew Bond Street, London $W_{1} S{ }_{1} \mathcal{D} Y, \mathcal{U} . \mathcal{K}$. Tel: +44 (o) 2074913520 - Fax: +44 (o) 2074919754 -

E-mail:jpmaps@attglobal.net - Website: www.jpmaps.co.uk- 
who come either for a class project or to do research in connection with their thesis. The number of faculty, graduate students, and external visitors remains low. These figures will undoubtedly change when the library Web site is fully operational.

Finally, regarding conservation, a great deal of work must be done to ensure the survival of the Fondo Reservado and the central library's collections. The new building provides a controlled environment (materials are kept at 72 degrees Fahrenheit with a relative humidity of 45 percent), but that that is not enough. Many other things have yet to be implemented, including extensive condition surveys (only a partial one was done on the oldest books one year ago by students taking a conservation course) and developing integrated pest management strategies. All these tasks, in addition to those regarding conservation matters, will have to be performed with flexibility and creativity and in collaboration with other, similar institutions. It is in our hands to turn the university library, a myth for many people, into a working reality. 